\title{
Empire of scholars
}

Universities, networks and the British academic world

$$
\text { I850-I939 }
$$

\section{TAMSON PIETSCH}

(

, a

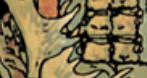

(1)

(3) $=3$
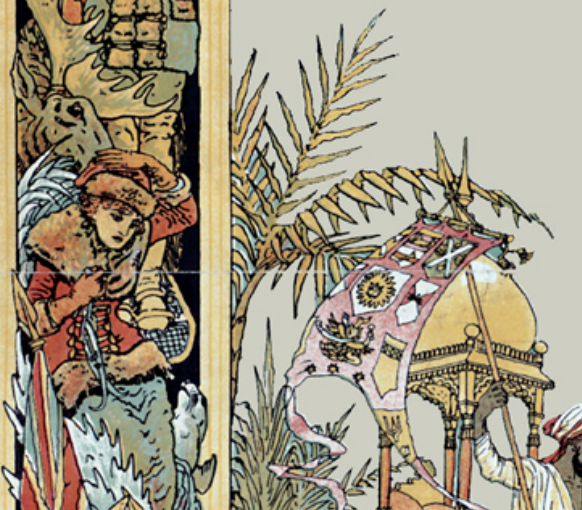

A. Aar w

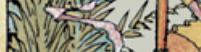




\section{-STUDIES IN- IMPERIALISM}

general editor John M. MacKenzie

When the 'Studies in Imperialism' series was founded more than twenty-five years ago, emphasis was laid upon the conviction that 'imperialism as a cultural phenomenon had as significant an effect on the dominant as on the subordinate societies'. With more than ninety books published, this remains the prime concern of the series. Cross-disciplinary work has indeed appeared covering the full spectrum of cultural phenomena, as well as examining aspects of gender and sex, frontiers and law, science and the environment, language and literature, migration and patriotic societies, and much else. Moreover, the series has always wished to present comparative work on European and American imperialism, and particularly welcomes the submission of books in these areas. The fascination with imperialism, in all its aspects, shows no sign of abating, and this series will continue to lead the way in encouraging the widest possible range of studies in the field. 'Studies in Imperialism' is fully organic in its development, always seeking to be at the cutting edge, responding to the latest interests of scholars and the needs of this ever-expanding area of scholarship.

Empire of scholars

MANCHESTER

Manchester University Press 


\author{
MUSEUMS AND EMPIRE \\ Natural history, human cultures and colonial identities \\ John M. MacKenzie \\ THE COLONISATION OF TIME \\ Ritual, routine and resistance in the British empire \\ Giordano Nanni \\ EMPIRE CAREERS \\ Working for the Chinese Customs Service, 1854-1949 \\ Catherine Ladds \\ LAW, HISTORY, COLONIALISM \\ The reach of empire \\ ed. Diane Kirkby and Catharine Coleborne \\ IMPERIAL CITIZENSHIP \\ Empire and the question of belonging \\ Daniel Gorman
}




\section{Empire of scholars}

\section{UNIVERSITIES, NETWORKS AND THE BRITISH ACADEMIC WORLD 1850-1939}

Tamson Pietsch

MANCHESTER UNIVERSITY PRESS Manchester and New York 
Copyright (C) Tamson Pietsch 2013

The right of Tamson Pietsch to be identified as the author of this work has been asserted by her in accordance with the Copyright, Designs and Patents Act 1988.

Published by MANCHESTER UNIVERSITY PRESS

Altrincham Street, Manchester M1 7JA

www.manchesteruniversitypress.co.uk

British Library Cataloguing-in-Publication Data

A catalogue record for this book is available from the British Library

Library of Congress Cataloging-in-Publication Data applied for

ISBN 9780719085024 hardback

First published 2013

The publisher has no responsibility for the persistence or accuracy of URLs for any external or third-party internet websites referred to in this book, and does not guarantee that any content on such websites is, or will remain, accurate or appropriate.

Typeset in Trump Medieval by Special Edition Pre-Press Services www.special-edition.co.uk 